\title{
Does Board of Directors Independence Behave Opportunistically or Ethically? Study Corporation Social Responsibility and Earning Management in Indonesia
}

Muhammad Taufik¹, Gideon Benhans²

DOI: https://doi.org/10.35838/jrap.2021.008.02.18

${ }^{1}$ Universitas Internasional Batam, Batam, Kepulauan Riau

${ }^{2}$ Universitas Internasional Batam, Batam, Kepulauan Riau

\section{ARTICLE INFO \\ JEL Classification: \\ M14; G34}

Key words:

corporation social responsibility, earnings management, board of directors independence, ethic, opportunis.

\begin{abstract}
This paper explores the opportunistic issues of EM and ethical issues of CSR where we aim to examine the relationship between CSR and $\mathrm{EM}$ and involve the role of BOD independence. Investigation of the relationship using corporate social performance theory where the research sample is a company that publishes sustainability reporting - GRI index for the period 2016 to 2019 in Indonesia. CSR does not affect EM, on the contrary, BOD independence has a positive and significant effect on EM. That is, BOD independence behaves opportunistically. Another finding is that BOD independence does not strengthen or weaken the relationship between CSR and EM. Therefore, despite being opportunistic, BOD independence does not use CSR as a reflection of ethical values to cover EM practices. This paper contributes to showing that BOD independence has 2 characters, namely opportunist on the one hand and ethical on the other.
\end{abstract}

\section{INTRODUCTION}

The quality of financial reporting is a substance of relevance value and becomes a fundamental goal for stakeholders to understand the actual situation (Obigbemi et al., 2016). The quality of financial reports is a reflection of the level of transparency and accountability (Katmon \& Farooque, 2017) and the level of conformity of financial accounting standards (Dimitropoulos, 2020). Earnings management is the most common proxy for representing the quality of financial reports (Dimitropoulos, 2020). Earnings management is a reflection of the output of management in managing financial statements by avoiding both small amounts of losses and profits (Dimitropoulos, 2020).

Previous studies put corporate social responsibility (CSR) as an observation tool on earnings management. The beginning of the emergence of the idea and practice of CSR is to fulfil the desirable or desire of the values of society (Bowen et al., 2013). But lately, CSR is used as a business strategy by management (Latif \& Sajjad, 2018; Porter \& Kramer, 2002). CSR practices are used as a business strategy to convince stakeholders that the company has a good reputation and image backup so that the company has the potential to get investment and funding projects (Aram, 1989; Arlow \& Gannon, 2011; Mescon \& Tilson, 1987). Management assures stakeholders that the company is responsible for any negative social and environmental implications of business operations (Amodu, 2018).

Continuing the discussion above, Gray et al. (1995), Deegan (2014), and Aaken \& Buchner (2020) state that company operations must run based on trust and ethical values to stakeholders, so that companies carry out CSR to gain legitimacy and avoid company operations that stop (Deegan \& Rankin, 1997; O'Donovan, 2002; Jordaan et al., 2018). CSR ethical actions are needed because it is suspected that management practices CSR to mitigate earnings management 
opportunistically (Abdullah \& Ismail, 2016; Abdullah \& Nasir, 2004).

On the other hand, management is also allowed to practice EM, as long as it complies with accounting standards. Management may engage in earnings management practices opportunistically and use CSR disclosures to cover these earnings management practices (Kumala \& Siregar, 2019). Muttakin et al. (2015) and Prior et al. (2008) found that management acts opportunistically and uses CSR activities to cover earnings management practices.

Furthermore, EM is the workout of management in financial reporting, so EM action is deliberate practice. Deliberate EM practices are intended for self-interest, such as receiving compensation related to sales, avoiding debt agreements and avoiding regulatory oversight (Choi et al., 2013; Xie et al., 2003). Therefore, one of the governance organs that represents and liaises with stakeholders is a board of commissioners (Buertey et al., 2020; Taufik \& William, 2021) which is independent to mitigate the adverse effects of EM (Buertey et al., 2020; Choi et al., 2013). The board of commissioners independent in Indonesia was changed by us with the term board of director independence (BOD independence) to represent globally accepted studies, while the executive represents management.

We capture that studies observing CSR and EM in Indonesia are rudimentary. Kumala \& Siregar (2019) made observations on CSR and EM by emphasizing the role of family companies as data samples. Meanwhile, we stress the CSR measurement method that publishes sustainability reporting that represents the GRI standard and fulfils 3 triple bottom line concepts, namely economic, social, and environmental (Wilburn \& Wilburn, 2013). Other studies, examining CSR and EM in the UK (Almahrog et al., 2018; Dimitropoulos, 2020), Bangladesh (Muttakin et al., 2015), Saudi Arabia (Habbash \& Haddad, 2020), and Pakistan (Ehsan et al., 2021).

Previous studies involving moderating variables can refer to (Mahrani \& Soewarno, 2018) that who treats EM to become moderating between BOD independence and financial performance. Ayu et al. (2020) treats EM to become mediating between CSR and financial performances, Suyono \& Farooque, (2018) tests BOD independence on EM and CSR, and Taufik \& William (2021) examines BOD education level as moderating between CSR and financial performance. Furthermore, the model from Cho \& Chun`s (2016) work observing CSR and EM moderated by the corporate governance index that his work has 2 weaknesses. There is no BOD independence in the index of corporate governance which is the key point of our article as a representation of supervision so that the objectives of the CSR paradigm are achieved, namely expectations for the company's economy and ethics (Carroll, 2004). Thus, at the best level of researchers, we contribute as the first group in Indonesia to empirically test CSR and EM moderated by BOD independence.

The remaining paper is divided into 4 parts. The second part shows the literature review and hypothesis development. The third part describes the research methodology. The fourth part discusses the empirical results and the last is the conclusion.

\section{LITERATURE REVIEW AND HYPOTHESIS DEVELOPMENT \\ Corporate Social Performances: The Grounded Theory to Capture Earning Management}

The definition of corporate social performance (CSP) is understood as "a business organization's configuration of principles of social responsibility, processes of social responsiveness, and policies, programs, and observable outcomes as they relate to the firm's societal relationships (Wood, 1991). CSP is different from stakeholder theory and legitimacy that are very dominantly used in explaining CSR. Referring to Deegan (2014), stakeholder theory captures the way companies carry out CSR practices by using two options, aimed at 
primary stakeholders or secondary stakeholders. Primary stakeholders illustrate ones without whose continuing participation the corporation cannot survive as a going concern, while secondary stakeholders represent who influence or affect, or are influenced or affected by, the corporation, but they are not engaged in transactions with the corporation and are not essential for its survival. theory concern to shows gains legitimacy from stakeholders which are a cycle of establishing, maintenance, defence legitimacy and loss legitimacy when a company chooses to abandon effort CSR. These theories stand on the foundation of CSR information publication, not illustrating how CSR impacts EM.

In contrast, Carroll (2004) describes CSP as a "pyramid of global corporate social responsibility" with and it is consist of 4 elements. Economic responsibility is doing what is required by global capitalism and gain profitable, legal responsibility is doing what is required by global stakeholders and obeys the law, ethical responsibility is doing what is expected by global stakeholders, and philanthropic responsibility is doing what is desired by global stakeholders and become good global corporate citizenship, arranged severally. This means that companies must contribute to solving social problems due to their operations, companies also have a pragmatic side to prevent companies from lawsuits while at the same time getting benefits in the form of economic value. This opens up opportunities for the relationship of CSR with earnings management practices.

\section{CSR and Earnings Management}

Many previous studies explore does CSR gain profitable and practice EM. Back to the discussion between CSR and EM, Dahlsrud (2008) argues five dimensions of CSR namely stakeholder, social, economic, environmental and voluntary. The purpose of the stakeholder dimension is CSR activities can increase good interactions between companies and stakeholders. CSR activities also contribute to overcoming social inequalities by integrating and considering operational impacts on society following the intent of the social dimension. Economic development carried out by companies can reduce the poor through CSR activities as intended by the economic dimension. Likewise for the environment, the company contributes to realizing a clean environment and care for the environment through CSR activities as an effort to fulfil the environmental dimension. Volunteer contribution to the community around the company through CSR activities as a fulfilment of the voluntary dimension. However, CSR activities have evolved, from being initially voluntary to a business strategy used to gain public trust to maximize their long-term return on investment and the sustainability of their business success (GrasGil et al., 2016; Latif \& Sajjad, 2018; Porter \& Kramer, 2002). Therefore, companies that drive CSR are used as a communication language (Wilburn \& Wilburn, 2013) and signal that financial statements that contain CSR information reflect quality income information (Choi et al., 2013).

Several studies have examined the effect of CSR on earnings management such as Kumala \& Siregar (2019) finding that CSR disclosure in mining companies in Indonesia has a negative relationship to earnings management which gives the interpretation that CSR disclosure can reduce earnings management practices because the company has contributed as their responsibility socially and environmentally. Kim et al. (2012) and Chih et al. (2008) found empirical evidence that companies that are committed to CSR provide a wider level of transparency and are less involved in earnings management practices. In contrast, some studies argue that managers can use CSR activities to cover up their opportunistic behaviour. Prior et al. (2008) found a positive relationship between CSR and earnings management and argued that CSR disclosure allows managers to cover up earnings management practices. Muttakin et al. (2015) found that corporate managers in Bangladesh might use CSR disclosure as a 
tool to distract stakeholders from continuing their opportunism.

To form a hypothesis, back to the empirical findings, that Chih et al. (2008) stated that the earnings management will not be covered by socially responsible companies so that the more companies carry out CSR practices, the accounting quality is higher and represents less profit manipulation. Referring to the explanation, the previous study differences between CSR disclosure and earnings management, the formulation of the first hypothesis is as follows:

H1: CSR disclosure has a negative and significant effect on earnings management

\section{BOD Independent Moderates Relationship between CSR and Earnings Management}

The board of directors (BOD) has the function of monitoring and supervising every policy taken by each executive in implementing their duties (Darwis, 2009; Taufik \& William, 2021). Moreover, BOD independence plays a role in aligning the interests of managers and stakeholders. Fama \& Jensen (1983) emphasize that the importance of independent BOD is to effectively monitor the activities and initiatives of managers so that a good corporate governance mechanism can be formed.

The BOC can emphasize the BOD in implementing social responsibility more effectively (Sembiring, 2005). Research conducted by Uzun et al. (2004), Kapoor \& Goel (2017), Jaggi et al. (2009), and Idris et al. (2018) found that a higher proportion of independent BOD allows BOD to contribute to oversight and hinders managers from performing earnings management, thereby placing financial statements at a transparent level.

On the other hand, referring to the research of (Qa`dan \& Suwaidan, 2019), companies are assessed not only by stakeholders from the company's financial statements, but companies must also be assessed from the CSR activities carried out. Arvidsson (2014) captures that investors only consider profit information (financial statements) and CSR when receiving information from companies.

As important as the role of $\mathrm{BOD}$ independence in monitoring, BOD independence can mitigate conflicting relationships between management and stakeholders (Buertey et al., 2020), so that BOD independence directs executives to carry out CSR without any other motives besides social, especially EM which is considered bad by stakeholders. Therefore, the formulation of the third hypothesis is as follows:

H2: BOD independence strengthen CSR has a negative and significant effect on earnings management

\section{RESEARCH METHOD}

The sample used in this study are companies listed on the Indonesia Stock Exchange from 2016 to 2019 and do not include the financial sector. We did not include the financial sector because Dechow et al. (1995) stated that adjusted discretionary accruals (ADA) as an instrument for measuring EM was estimated by adjusting changes in sales to the company's receivables and the absence of sales receivable accounts in the financial sector companies. According to Dechow et al. (1995), such estimates can allow companies to manipulate sales by changing credit agreements. The selection of samples that did not involve financial sector companies was also investigated by several researchers (Cho \& Chun, 2016; Gras-Gil et al., 2016; Hong \& Andersen, 2011; Kothari et al., 2005; Muttakin et al., 2015; Prior et al., 2008; Scholtens \& Kang, 2013). We use adjusted discretionary accrual (ADA) measurement as earnings management which has been modified by Kothari et al. (2005) and Kumala \& Siregar (2019).

$$
\begin{gathered}
T A_{i t}=\beta_{0}+\beta_{1} \frac{1}{A S S E T_{i t}}+\beta_{2}\left(\triangle S A L E S_{i t}-\triangle A R_{i t}\right) \\
+\beta_{3} P P E_{i t}+\beta_{4} R O A_{i t-1}+\in_{i t} \\
T A_{i t} \text { : total accrual }
\end{gathered}
$$

ASSET $_{\text {it }}$ : average total assets $\triangle \mathrm{SALES}_{\mathrm{it}}-\triangle \mathrm{AR}_{\mathrm{it}}$ : change in sales minus change in accounts receivable divided by 
average total assets

$\mathrm{PPE}_{\mathrm{it}}$ : net value of property, plant, and equipment

$\mathrm{ROA}_{\text {it-1 }}$ : return on assets of the previous year

The sample companies also have criteria, namely reporting financial statements and annual reports consistently from 2016 to 2019 and reporting social responsibility activities according to the G4 global reporting initiative (GRI) index consistently. We chose the GRIG4 index as a criterion because GRI has a substantial and critical structure in the area of sustainability reporting as well as generally accepted standards and demonstrates a strong dedication to environmental issues (Barkemeyer et al., 2015; Del Mar AlonsoAlmeida et al., 2014; Gümrah et al., 2019). In addition, the GRI index was chosen because it is acceptable in all types of industries and is the most comprehensive in terms of economic, environmental and social aspects (Wilburn \& Wilburn, 2013).

CSR disclosure as an independent variable is measured by GRI as a reference and using the GRI G4 indicator which contains 91 items, consisting of 9 economic disclosures, 34 environmental disclosures and 34 social disclosures. The index calculation refers to the research of Haniffa \& Cooke (2005), namely the percentage of items disclosed in the CSR report. The moderating variable in this study is the proportion of independent BOD (BODIND) measured by the percentage of independent commissioners in a company by referring to the research of Buertey et al. (2020).

In this study, there are several control variables. Firm size (SIZE) provides information on the size of a company and is measured by the natural logarithm of the company's total assets. Moreover, large companies tend to avoid earnings management practices and have more disclosures so that large companies tend to have better earnings quality (Watts et al., 1978). Leverage (LEVE) is calculated by the ratio of non-current debt to total assets. Companies with high levels of leverage are more likely to practice earnings management due to avoiding debt covenant violations or reducing debt contract costs (Press \& Weintrop, 1990). Growth (GROWTH) is measured by the percentage change in sales for the previous year and the current year. Growth can attract the attention of stakeholders and tends to have a high level of discretionary accruals towards earnings management (Myers et al., 2007; Skinner \& Sloan, 2002). Company age (AGE) can reflect the maturity level of a company in dealing with problems and tends to be stable in growth. Company age affects discretionary accruals because developing companies tend to have higher discretionary accruals, while companies that have reached a stable level tend to have lower discretionary accruals (McNichols, 2002). Company age (FAGE) is measured by the natural logarithm of the length of time they have been listed on the stock exchange, namely using monthly units. Finally, companies with good net income (NI) in the previous year tend to practice earnings management to maintain their performance for the next period (Handayani et al., 2009). Net income is measured using a dummy variable, where 1 indicates the previous year's income is positive and 0 otherwise. These research models can be expressed in the following equation.

$$
\begin{array}{rl}
E M=\beta_{0}+\beta_{1} C & S R_{1}+\beta_{2} \text { BODIND }_{2} \\
& +\beta_{3} \text { CSRBODIND }_{3}+\beta_{4} \text { SIZE }_{4} \\
& +\beta_{5} \text { FAGE }_{5}+\beta_{6} \text { NI I }_{6} \\
& +\beta_{7} \text { GROWTH } \text { HOW }_{7}+\beta_{8} L E V E_{8} \\
& +\varepsilon_{\ldots \ldots} \ldots(1)
\end{array}
$$

\section{RESULTS AND DISCUSSION}

The sample companies have criteria, namely reporting financial statements and annual reports consistently from 2016 to 2019 and reporting social responsibility activities according to the GRI G4 index consistently. Based on the selection of sample criteria in Table 1, the number of observed data is 120 data. 
Table 1 Samples

\begin{tabular}{lc}
\hline Companies listed on the Indonesia Stock Exchange 2016-2019 & 486 \\
\hline Financial and bank category companies & $(65)$ \\
Companies that do not meet the criteria & $(391)$ \\
Companies that meet the criteria & 30 \\
Observation year & 4 \\
Number of data & 120 \\
\hline
\end{tabular}

Table 2. Descriptive statistics

\begin{tabular}{ccccc}
\hline Variabel & Min & Max & Mean & Std \\
\hline ADA & $-0,57715$ & 1,12657 & 0,47620 & 0,29181 \\
CSRD & 0,07870 & 0,79139 & 0,36195 & 0,16322 \\
BODIND & 0,16667 & 0,80000 & 0,39286 & 0,10010 \\
SIZE & 28,71302 & 33,49453 & 30,99126 & 1,06274 \\
FAGE & 3,46574 & 6,23048 & 5,26202 & 0,65743 \\
GROWTH & $-0,43801$ & 67,42921 & 0,75662 & 6,20037 \\
LEVE & 0,01468 & 1,65132 & 0,23531 & 0,19584 \\
\hline
\end{tabular}

Notes: ADA is adjusted disretionary accrual; CSRD is corporate social responsibility disclosure; BODIND is BOD Independence; SIZE is firm size; FAGE is firm age; GR is Growth; and LEV is Leverage

Table 3. Descriptive statistics Dummy Variabel

\begin{tabular}{ccccc}
\hline Variabel & Min & Max & Mean & Std \\
\hline NI & - & 1,0000 & 0,5500 & 0,4970 \\
\hline
\end{tabular}

Note: NI is profit performance dummy for positive with other values 1 and 0

The results of descriptive statistics for the dependent variable, namely earnings management (ADA) show the average value is 0.4760 which indicates the company is practising earnings management. The results of the descriptive statistics for the independent variable, namely CSRD, in table 2 show that CSR disclosure is on average 34 items out of 91 items. The results of descriptive statistics for BOD independence show an average value of 39 per cent that has complied with the Regulation of the Financial Services Authority No. 33/POJK.04/2014 where companies are required to have independent commissioners of at least 30 per cent of all members of the board of director.

\section{Result CSR and BOD Independence Towards EM}

Table 4 shows that CSR does not affect $\mathrm{EM}$, at -0.124 . That is, CSR does not show any attachment to earnings management so that
CSR practices are not used as a tool to carry out that practice. On the other hand, the focus of companies conducting activities and disclosing CSR information is to gain legitimacy from stakeholders and improve the company's reputation and image. Therefore, CSR practices are motivated by honest, transparent and ethical attitudes rather than focusing on increasing profits (Almahrog et al., 2018).

On the other hand, BOD independence shows a positive and significant result for EM, which is 0.667 with an error rate of $1 \%$. These results indicate that independent BOD plays a role in earnings management practices. This finding is in line with the research of Chatterjee (2020), Khalil \& Ozkan (2016), Orazalin (2020), Wan Mohammad \& Wasiuzzaman (2019) that the existence of an independent BOD is not a barrier to earnings management. BOD independence should not be involved in earnings management (Uzun 
et al., 2004, Kapoor \& Goel, 2017, Jaggi et al., 2009, and Idris et al., 2018).

\section{Result BOD Independence Moderate CSR and EM}

BOD independence is not able to moderate the relationship between CSR and EM, at 2.090. Substantially, this finding strengthens the previous discussion, CSR has no effect on EM and although BOD independence has a significant effect on EM, the tool used is not CSR.
BOD independence protects shareholders from their opportunistic behaviour to seeking personal gain (Kiel \& Nicholson, 2003). On the other hand, CSR is an ethical behaviour to contribute to the environment and society (Carroll, 2004). CSR is a social activity based on ethical behaviour which would be inappropriate if used as a tool for EM practice. BOD independence is suspected of using other instruments to encourage EM practices.

Table 4. Result

\begin{tabular}{|c|c|c|}
\hline Variables & $\begin{array}{c}\text { CSR and BOD } \\
\text { independence towards EM }\end{array}$ & $\begin{array}{l}\text { BOD independence } \\
\text { moderate CSR and EM }\end{array}$ \\
\hline \multirow{2}{*}{ CSRD } & -0.124 & 0,61388889 \\
\hline & $(0.161)$ & $(0.660)$ \\
\hline \multirow[t]{2}{*}{ BODIND } & $0.677^{* * *}$ & -0.981 \\
\hline & $(0.251)$ & (0.903) \\
\hline \multirow[t]{2}{*}{ CSRDBODIND } & n.a. & 2.090 \\
\hline & n.a. & -2.168 \\
\hline \multirow[t]{2}{*}{ SIZE } & -0.0335 & -0.0352 \\
\hline & $(0.0249)$ & $(0.0250)$ \\
\hline \multirow[t]{2}{*}{ NI } & -0.0350 & -0.0363 \\
\hline & $(0.0499)$ & (0.0499) \\
\hline \multirow[t]{2}{*}{ FAGE } & $0.0869^{* *}$ & $0.0869^{* *}$ \\
\hline & (0.0397) & $(0.0397)$ \\
\hline \multirow[t]{2}{*}{ GROWTH } & 0.000833 & 0.000760 \\
\hline & $(0.00402)$ & $(0.00402)$ \\
\hline \multirow[t]{2}{*}{ LEVE } & $-0.374^{* * *}$ & $-0.369 * * *$ \\
\hline & $(0.136)$ & $(0.136)$ \\
\hline \multirow[t]{2}{*}{ Constant } & 0,65416667 & 1.238 \\
\hline & $(0.773)$ & $(0.832)$ \\
\hline Obs & 120 & 120 \\
\hline R-squared & 0.207 & 0.214 \\
\hline
\end{tabular}

CSRD is corporate social responsibility disclosure; BODIND is BOD Independence; SIZE is firm size; FAGE is firm age; GR is Growth; and LEV is Leverage; NI is net income; and *,**, *** indicate significance at the $10 \%, 5 \%$, and $1 \%$ levels

Source: Stata output v.16

\section{CONCLUSION}

This study captures how companies treat CSR towards EM, and how the role of BOD independence in their relationship. CSR is not used in conducting EM practices. Furthermore, BOD independence has a role in EM practices but surprisingly does not involve CSR with EM practices. This is based on two contradictory behaviours, CSR is motivated by ethical behaviour while EM is motivated by opportunistic behaviour. Although BOD independence contributes to improving EM practices, it uses other instruments besides CSR.

In this study, there are various limitations. This study does not yet 
understand what drives BOD independence in practising EM. Empirical studies need to be done, and what are the motives behind BOD in practising EM. This study also has not found what types of characteristics inherent in BOD are able to strengthen the negative relationship between CSR and EM. Maybe in the future, researchers can examine diversity issues such as gender, age, and education. We don't take this issue, because it ignores the issue of diversity and focuses on the issue of independence.

\section{REFERENCES}

Aaken, D. Van, \& Buchner, F. (2020). Religion and CSR: a systematic literature review. Journal of Business Economics, 90(5-6), 917-945.

https://doi.org/10.1007/s11573-02000977-z

Abdullah, S. N., \& Ismail, K. N. I. K. (2016). Women directors, family ownership and earnings management in Malaysia. Asian Review of Accounting, 24(4), 525550. https://doi.org/10.1108/ARA-072015-0067

Abdullah, S. N., \& Nasir, N. M. (2004). Accrual management and the independence of the boards of directors and audit committees. IIUM Journal of Economics and Management, 12(1), 1-31.

Almahrog, Y., Ali Aribi, Z., \& Arun, T. (2018). Earnings management and corporate social responsibility: UK evidence. Journal of Financial Reporting and Accounting, $\quad 16(2), \quad 311-332$. https://doi.org/10.1108/JFRA-11-20160092

Amodu, N. (2018). Corporate social responsibility as catalyst for development: Prospects and challenges in Nigeria. Developments in Corporate Governance and Responsibility, 24, 207228. https://doi.org/10.1108/S2043052320180000014010

Arvidsson, S. (2014). Corporate social responsibility and stock market actors: A comprehensive study. Social Responsibility Journal, 10(2), 210-225. https:// doi.org/10.1108/SRJ-08-20120099

Ayu, M., Lindrianasari, Gamayuni, R. R., \& Urbański, M. (2020). The impact of environmental and social costs disclosure on financial performance mediating by earning management. Polish Journal of Management Studies, 21(2), $74-86$ https:// doi.org/10.17512/pjms.2020.21. 2.06

Barkemeyer, R., Preuss, L., \& Lee, L. (2015). On the effectiveness of private transnational governance regimesEvaluating corporate sustainability reporting according to the Global Reporting Initiative. Journal of World Business, 50(2), 312-325. https:// doi.org/10.1016/j.jwb.2014.10.0 08

Bowen, H. R., Bowen, P. G., \& Gond, J. P. (2013). Social responsibilities of the businessman. In Social Responsibilities of the https:// doi.org/10.2307/3708003

Buertey, S., Sun, E. J., Lee, J. S., \& Hwang, J. (2020). Corporate social responsibility and earnings management: The moderating effect of corporate governance mechanisms. Corporate Social Responsibility and Environmental Management.

https:// doi.org/10.1002/csr.1803

Chatterjee, C. (2020). Board quality and earnings management: Evidence from India. Global Business Review, 21(5), 13021324.

https://doi.org/10.1177/097215091985 6958

Cho, E., \& Chun, S. (2016). Corporate social responsibility, real activities earnings management, and corporate governance: evidence from Korea. AsiaPacific Journal of Accounting and Economics, 23(4), 400-431. 
https://doi.org/10.1080/16081625.2015 .1047005

Choi, B. B., Lee, D., \& Park, Y. (2013). Corporate social responsibility, corporate governance and earnings quality: Evidence from Korea. Corporate Governance: An International Review, 21(5), 447-467. https://doi.org/10.1111/corg.12033

Deegan, C. (2014). An overview of legitimacy theory as applied within the social and environmental accounting literature. In Sustainability Accounting and Accountability: Second Edition (pp. 248272).

Del Mar Alonso-Almeida, M., Llach, J., \& Marimon, F. (2014). A closer look at the "Global Reporting Initiative" sustainability reporting as a tool to implement environmental and social policies: A worldwide sector analysis. Corporate Social Responsibility and Environmental Management, 21(6), 318335. https://doi.org/10.1002/csr.1318

Dimitropoulos, P. E. (2020). Corporate social responsibility and earnings management in the EU: a panel data analysis approach. Social Responsibility Journal, April. https://doi.org/10.1108/SRJ-04-20200156

Ehsan, S., Tariq, A., Nazir, M. S., Shabbir, M. S., Shabbir, R., Lopez, L. B., \& Ullah, W. (2021). Nexus between corporate social responsibility and earnings management: Sustainable or opportunistic. Managerial and Decision Economics, https://doi.org/10.1002/mde.3396

Gras-Gil, E., Palacios Manzano, M., \& Hernández Fernández, J. (2016). Investigating the relationship between corporate social responsibility and earnings management: Evidence from Spain. BRQ Business Research Quarterly, 19(4), 289-299. https://doi.org/10.1016/j.brq.2016.02.0
02

Gümrah, A., Güngör Tanç, Ş., \& Tanç, A. (2019). Scoring of sustainability reports with gri-g4 economic, environmental, and social performance indicators: A research on the companies preparing sustainability report in turkey. Accounting, Finance, Sustainability, Governance and Fraud, I, 133-151. https:// doi.org/10.1007/978-981-133203-6_8

Habbash, M., \& Haddad, L. (2020). The impact of corporate social responsibility on earnings management practices: evidence from Saudi Arabia. Social Responsibility Journal, 16(8), 1073-1085. https:// doi.org/10.1108/SRJ-09-20180232

Idris, M., Abu Siam, Y., \& Nassar, M. (2018). Board independence, earnings management and the moderating effect of family ownership in Jordan. Management and Marketing, 13(2), 985994. https:// doi.org/10.2478/mmcks2018-0017

Jaggi, B., Leung, S., \& Gul, F. (2009). Family control, board independence and earnings management: Evidence based on Hong Kong firms. Journal of Accounting and Public Policy, 28(4), 281300.

https:// doi.org/10.1016/j.jaccpubpol.2 009.06.002

Jordaan, L. A., de Klerk, M., \& de Villiers, C. J. (2018). Corporate social responsibility and earnings management of South African companies. South African Journal of Economic and Management Sciences, 21(1), 1-13. https:// doi.org/10.4102/ sajems.v21i1.1 849

Kapoor, N., \& Goel, S. (2017). Board characteristics, firm profitability and earnings management: Evidence from India. Australian Accounting Review, 27(2), 180-194. https://doi.org/10.1111/auar.12144 
Katmon, N., \& Farooque, O. Al. (2017). Exploring the impact of internal corporate governance on the relation between disclosure quality and earnings management in the UK listed companies. Journal of Business Ethics, 142(2),

345-367. https://doi.org/10.1007/s10551-0152752-8

Khalil, M., \& Ozkan, A. (2016). Board independence, audit quality and earnings management: Evidence from Egypt. Journal of Emerging Market Finance, 15(1), 84-118. https://doi.org/10.1177/097265271562 3701

Kim, Y., Park, M. S., \& Wier, B. (2012). Is earnings quality associated with corporate social responsibility? Accounting Review. https://doi.org/10.2308/accr-10209

Kothari, S. P., Leone, A. J., \& Wasley, C. E. (2005). Performance matched discretionary accrual measures. Journal of Accounting and Economics, 39(1), 163197.

https://doi.org/10.1016/j.jacceco.2004. 11.002

Kumala, R., \& Siregar, S. V. (2021). Corporate social responsibility, family ownership and earnings management: the case of Indonesia. Social Responsibility Journal, 17(1), 69-86. https://doi.org/10.1108/SRJ-09-20160156

Latif, K. F., \& Sajjad, A. (2018). Measuring corporate social responsibility: A critical review of survey instruments. Corporate Social Responsibility and Environmental Management, 25(6), 1174-1197. https://doi.org/10.1002/csr.1630

Mahrani, M., \& Soewarno, N. (2018). The effect of good corporate governance mechanism and corporate social responsibility on financial performance with earnings management as mediating variable. Asian Journal of Accounting
Research, 3(1), 41-60. https:// doi.org/10.1108/ajar-06-20180008

Mansour, W., \& Jlassi, M. (2014). The effect of religion on financial and investing decisions. In H. kent Baker \& V. Ricciardi (Eds.), Investor Behavior: The Psychology of Financial Planning and Investing (Issue 2011, pp. 135-151). John Wiley \& Sons, Inc.

https://doi.org/10.1002/978111881345 4.ch8

Muttakin, M. B., Khan, A., \& Azim, M. I. (2015). Corporate social responsibility disclosures and earnings quality: Are they a reflection of managers' opportunistic behavior? Managerial Auditing Journal, 30(3), 277-298. https:// doi.org/10.1108/MAJ-02-20140997

O’Donovan, G. (2002). Environmental disclosures in the annual report: Extending the applicability and predictive power of legitimacy theory. Accounting, Auditing \& Accountability Journal, 15(3), 344-371. https:// doi.org/10.1108/095135702104 35870

Obigbemi, I. F., Omolehinwa, E. O., Mukoro, D. O., Ben-Caleb, E., \& Olusanmi, O. A. (2016). Earnings management and board structure: Evidence from Nigeria. SAGE Open, $6(3)$. https:// doi.org/10.1177/215824401666 7992

Orazalin, N. (2020). Board gender diversity, corporate governance, and earnings management: Evidence from an emerging market. Gender in Management, 35(1), $37-60$. https:// doi.org/10.1108/GM-03-20180027

Qa`dan, M. B. A., \& Suwaidan, M. S. (2019). Board composition, ownership structure and corporate social responsibility disclosure: the case of Jordan. Social Responsibility Journal, 15(1), 28-46. 
https://doi.org/10.1108/SRJ-11-20170225

Scholtens, B., \& Kang, F. C. (2013). Corporate social responsibility and earnings management: Evidence from Asian economies. Corporate Social Responsibility and Environmental Management, 20(2), 95-112.

https://doi.org/10.1002/csr.1286

Suyono, E., \& Farooque, O. Al. (2018). Do governance mechanisms deter earnings management and promote corporate social responsibility? Accounting Research Journal, 31(3), 479-495. https://doi.org/10.1108/ARJ-09-20150117

Taufik, M., \& William, T. (2021). Does BOC`s characteristics moderate the effect of corporate social responsibility on performance? Evidence of Indonesian mining companies. Journal of Applied Accounting and Taxation, 6(2), 137-146.

Wan Mohammad, W. M., \& Wasiuzzaman, S. (2019). Effect of audit committee independence, board ethnicity and family ownership on earnings management in Malaysia. Journal of Accounting in Emerging Economies, 10(1), 74-99. https://doi.org/10.1108/JAEE01-2019-0001

Wilburn, K., \& Wilburn, R. (2013). Using Global Reporting Initiative indicators for CSR programs. Journal of Global Responsibility, 4(1), 62-75. https:// doi.org/10.1108/204125613113 24078 